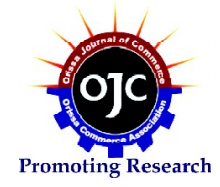

Orissa Journal of Commerce

Vol. 42, Issue 3, July-September 2021

ISSN: 0974-8482

(C) OJC India. All Right Reserved

URL: www.ojcoca.org

DOI: https://doi.org/10.54063/ojc.2021.v42i03.09

\title{
Impact of Cultural Determinants on Bilateral Trade of India
}

\author{
Anurag Maurya ${ }^{1 *}$ and Shilpa Garg ${ }^{2}$ \\ ${ }^{1}$ Research Scholar, Department of Commerce, Delhi School of Economics, University of Delhi, Delhi. E-mail: anurag740@gmail.com \\ ${ }^{2}$ Assistant Professor, College of Vocational Studies, University of Delbi, Delbi.E-mail: shilpa9711@yahoo.com \\ ${ }^{*}$ Corresponding Author
}

To cite this paper

Maurya, A., \& Garg, S. (2021). Impact of Cultural Determinants on Bilateral Trade of India. Orissa Journal of Commerce. 42(3), 109-119.

Keywords

Colonial link, Cultural distance, Gravity model, Bilateral trade, Cultural determinants

JEL Classification F21, F23, O43, O53

\begin{abstract}
Culture was defined by Hofstede as "the collective programming of the mind", which distinguishes people from one another and that can affect various social, economic and political transactions. They play a very significant role in affecting global trade transactions, especially for a country like India with such strong and deeply rooted cultural values. This paper has analyzed the role of cultural factors in determining India's bilateral trade with 76 trading partner countries for the year 2018. 'Cultural distance' and 'colonial links' have been used as cultural determinants, where 'cultural distance' is measured using the six dimensions of culture given by Hofstede. An extended gravity model of trade has been used to test their impact on India's exports, imports and total trade. Our analysis revealed a positive impact of 'colonial links' and a negative though insignificant effect of 'cultural distance' on India's trade variables.
\end{abstract}

\section{Introduction}

Culture simply represents the 'way of life' of a group of people. It includes their beliefs, values, norms as well as social behaviours. Hofstede (2013) defined culture as the "collective programming of the mind distinguishing the members of one group or category of people from others".

Indian culture is very rich and historic. Garg (2019) laid some key aspects of cultural norms existing in India: Though Hinduism and Hindi language has got a substantial share in Indian culture, but there are a large number of other coexisting religions and languages. There also exist a mixture of individualism and collectivism in Indian behaviour, and long term as well as short term approach in thinking. A clear preference is visible for hierarchical top down system with a practice of displaying one's success and power in abundance. Uncertainty and ambiguity are also comfortably accepted with overall culture being restrained in nature.

Existence of such a complex, diverse and deeply rooted culture makes India a unique country. But cultural differences with other nations can severally impact its global transactions. Kogut and Singh (1988) elaborated the concept of cultural differences, so as to indicate how common values and norms of one nation are different from other nations. Such differences between trading partners have 
been found to act as a barrier to trade. Huge gaps in cultural values and norms increase the difficulty of trading partners in understanding as well as predicting each other's trading behaviour (Elsass and Veiga, 1994), thus bringing unnecessary uncertainty in global transactions. This also confounds the economic interaction and realization of business deals (Parkhe, 1991).

Present study empirically examines how cultural differences between India and its trading partners can affect their bilateral trade flows. The paper has been structured in different sections, as follows: Section two covers the existing literature studying the effect of culture on international trade, this section also talks about Hofstede's cultural framework, section three presents objective and rationale for the present study, section four presents our research model and the methodology employed, section five discusses our results and lastly the final section draws the conclusion of our study.

\section{Review of Literature}

\subsection{Culture and Trade}

A number of studies have tried to explore the relationship between trade and culture; a few of them have been discussed here.

Guo (2004) analysed the impact of cultural factors on trade, using panel data of the US and China. The study found that linguistics links have more influence on trade as compared to geographical proximity. It further indicates that linguistics links are more significant for China than US trade and religious dissimilarities are less significant for both the US and China. It discourages trade in poorer countries while encourages trade in wealthier countries. Linders et al. (2005) studied how institutional as well as cultural distances affect bilateral trade flows of merchandise exports. They used a gravity model for a sample of 92 economies in year 1999. Culture was measured using Hofstede's dimensions. Cultural distance was found to have a positive effect on bilateral trade as larger cultural distance signifies larger differences in management practices, which makes trade a preferable option as compared to other options of local production.

Felbermayr and Toubal (2010) argued that empirical quantification and testing of cultural variable is very difficult due to lack observability and elusiveness of concept. The study measured cultural proximity (which varies with time and country pairs), by using a bilateral score data obtained via some European TV show. By using the gravity model, study concluded that cultural proximity has positive links with bilateral trade. Tadesse and White (2010) explored the impact of cultural distance to initiate and conclude trade deals between trading partners. By using data of 67 countries for the period of 1996 to 2001 in modified gravity model, the study concluded that the cultural dissimilarities (lack of trust) have negative and significant impact on aggregate and disaggregated trade flows.

Cyrus (2012) examined the role of cultural proximity on international trade by using gravity model. The cultural proximity was measured using the data on World Value Survey that include questions regarding trust, respect, control and obedience. The study found bi-directional relationship between trade and cultural distance i.e. cultural distance between countries discourages their bilateral trade and bilateral trade in countries helps in bridging cultural distance between countries. Gokmen (2017) investigated the effects of cultural differences on global trade over the years. Culture was used to reflect trust, values, norms as well as information cost. Cultural differences were found to have an 
Impact of Cultural Determinants on Bilateral Trade of India

adverse impact on trade and such negative impact has increased over the period of time. It was also shown that differences in cultural environment have become a more prominent barrier in global trade after the period of Cold War.

The present study complements this previous research work in two ways. First, we have included cultural distance in well-established model of trade i.e. Gravity model to explain bilateral trade flows. Secondly, while in previous work cultural familiarity or unfamiliarity has been measured using dummy variables for different aspects of culture, common language, common religion or colonial links (Srivastava and Green, 1986); our study has also measured the cultural and colonial links between India and its trading partners.

\subsection{Hofstede's Cultural Framework}

Hofstede (1980) gave cultural scores to individual countries, which is a good measure of cultural distance between countries (Kogut and Singh, 1988). He calculated the scores using survey data of 1,16,000 employees of IBM from 40 countries. He identified four dimensions of culture on which countries differ to each other:

- Power Distance: This dimension shows how much inequality and concentration of power is acceptable in a social framework.

- Uncertainty Avoidance: It considers the extent to which Individual are comfortable to deal with ambiguity and uncertainty.

- Masculinity vs. Feminity: It shows the preference of society for achievement, sexual equality, and behaviour. Masculinity refers to certain characteristics such as different gender roles, concentration on wealth building or material success, assertiveness etc.

- Individualism vs. Collectivism: It refers to the extent to which people are integrated in groups and societal interests prevail over the individual interests.

His subsequent work included more respondents from different fields, such as pilots, students, managers, consumers and elites from different countries, so as to validate previous findings and extend their scope by including two more dimensions:

- Long Term vs. Short Term Orientation: It measures the degree of preference of a society to follow time honoured tradition and norms and reluctance for adopting new societal changes.

- Indulgence vs. Restraint. Indulgence measures whether people in a society can freely enjoy their lives i.e. free gratification of their needs.

Hofstede et al. (2010) assigned scores ranging from 0 to 100 to seventy-six countries on all the six dimensions, which have been published in the book titled "Cultures and Organizations: Software of the Mind".

While the existing literature has mostly focussed on few linguistic and religious aspects of culture, our study tries to cover their wider aspects. Thus, two variables have been used in our study to account for the cultural gaps, where along with 'colonial links', we have also created a new variable named 'cultural distance'. The 'cultural distance' variable is based on the well-established cultural framework of Hofstede et al. (2010), which goes far beyond than previous measures of culture which were based on familiarity in religion or language only. This wider measure is based on six dimensions of culture 
and is thus able to capture the differences in shared values and norms between countries in a better manner. Since, the previous research model has measured cultural dissimilarity between trading countries with dummy variables (De Groot et al., 2004), in present study the cardinal measure is used to captures the extent to which different aspects of culture level differ.

\section{Objective and Hypothesis of the Study}

\subsection{Objective of the Study}

The main objective of the study is:

- To examine empirically how cultural differences between India and its trading partners affect their bilateral trade flows.

\subsection{Hypothesis of the Study}

The hypothesis of this paper is:

- 'Colonial links' and 'cultural distance' have no impact on bilateral trade.

\section{Research Methodology}

Gravity model of trade includes various control variables which affect the flow of trade between economies. Timbergen (1962) and Poyhonen (1963) explained gravity equation of trade as: the volume of trade between two nations is directly proportional to their masses i.e. GDPs and inversely related to their distance. An extended version of gravity model is used by including dummy variables for colonial link of trading partners. To estimate the results, multiple regression method is used. Our log-log gravity model includes GDP, geographical distance, difference in per capita income, trade openness, cultural distance and colonial link as explanatory variables while merchandise trade, exports and imports as explained variables. Final model is as follows:

$$
\mathrm{L}\left(\mathrm{T}_{\mathrm{ij}}\right)=\alpha+\beta_{1} \mathrm{~L}\left(\mathrm{GDP}_{\mathrm{j}}\right)+\beta_{2} \mathrm{~L}\left(\mathrm{DIS}_{\mathrm{ij}}\right)+\beta_{3} \mathrm{~L}\left(\mathrm{DGDP}_{\mathrm{ij}}\right)+\beta_{4} \mathrm{~L}\left(\mathrm{TO}_{\mathrm{j}}\right)+\beta_{5}\left(\mathrm{CD}_{\mathrm{ij}}\right)+\beta_{6}\left(\mathrm{COL}_{\mathrm{ij}}\right)
$$

Where,

$T_{i j}$ - trade/exports/imports between $i_{\text {th }}$ country i.e. India and its partner $j_{\text {th }}$ country.

$\mathrm{GDP}_{j}$ - GDP of trading partner.

DIS $_{\mathrm{ij}}$ - distance between India and $\mathrm{j}_{\text {th }}$ trading partner. The geographical distance between India and its trading partner is taken as air travel distance in miles.

$\mathrm{TO}_{j}$ - trade openness of trading partner (ratio of trade to GDP).

$\mathrm{COL}_{\mathrm{ij}}$ - dummy variable for colonial link between India and its trading partner.

$\mathrm{CD}_{\mathrm{ij}}$ - Cultural gap between India and its trading partner. To measure cultural differences between countries, we have used Hofstede's et al. (2010) score on six dimensions of national culture. The cultural difference is measured as follows:

$$
C D_{i j}=\frac{1}{6} \sum_{c=1} \frac{\left(C_{c i}-C_{c j}\right)^{2}}{V_{c}}
$$


Impact of Cultural Determinants on Bilateral Trade of India

Where,

$\mathrm{C}_{\mathrm{ci}}$ is country i's score on $\mathrm{C}_{\mathrm{th}}$ dimension of Hofstede's Index.

$\mathrm{V}_{\mathrm{c}}$ is the variance of $\mathrm{c}_{\mathrm{th}}$ dimension across all countries.

The above model was propounded by Kogut and Singh (1988) and it was further used by various authors such as Barkema and Vermeulen (1997); Park and Ungson (1997); Brouthers and Brouthers (2001).

Since culture is mainly a time invariant variable, so the data has been taken for the most recent year i.e. 2018 for which data of all the variables was available at the time of conducting the research. The bilateral trade data is collected from ITC Database for India's 76 trade partner countries for the year 2018. The GDPs and Trade Openness data is collected from World Bank Indicators. The variable geographical distance between two countries is calculated by taking distance between their capitals. The distance is measured in miles and their data is collected from various online sources. The information about the colonial link between countries is collected from various articles. The data of cultural dimensions are taken from Hofstede's website.

\section{Results and Discussion}

Table 1 presents the descriptive statistics for complete data. The Shapiro-Wilk (1965) test is used to test the normality. The null hypothesis for the test which says that the sample is drawn from normally distributed population cannot be rejected at 5 per cent significance level for all the variables.

Table 1: Descriptive Statistics

\begin{tabular}{lrrrrrrrr}
\hline & $\begin{array}{c}\text { Cultural } \\
\text { Distance }\end{array}$ & L_GDP & L_DIFF & L_TO & L_DIS & L_IMP & L_EX & L_Trade \\
\hline $\mathrm{N}$ & 72 & 72 & 72 & 72 & 72 & 72 & 72 & 72 \\
Mean & 1.49 & 11.5 & 3.95 & -0.123 & 3.55 & 6.19 & 6.17 & 6.54 \\
Std. error mean & 0.0823 & 0.0774 & 0.0852 & 0.0316 & 0.0297 & 0.0940 & 0.0748 & 0.0800 \\
Median & 1.43 & 11.5 & 4.11 & -0.130 & 3.58 & 6.13 & 6.21 & 6.49 \\
Mode & 1.76 & $10.2 \mathrm{a}$ & $2.27 \mathrm{a}$ & $-0.418 \mathrm{a}$ & 3.60 & $4.55 \mathrm{a}$ & $5.07 \mathrm{a}$ & 5.27 \\
Standard deviation & 0.699 & 0.657 & 0.718 & 0.268 & 0.252 & 0.798 & 0.635 & 0.679 \\
Minimum & 0.300 & 10.2 & 2.27 & -0.697 & 2.80 & 4.55 & 5.07 & 5.27 \\
Maximum & 3.40 & 13.3 & 4.91 & 0.575 & 4.02 & 7.87 & 7.71 & 7.95 \\
Skewness & 0.364 & 0.376 & -0.544 & 0.112 & -0.646 & -0.103 & 0.0833 & -0.0558 \\
Std. error skewness & 0.283 & 0.283 & 0.285 & 0.283 & 0.283 & 0.283 & 0.283 & 0.283 \\
Kurtosis & -0.392 & 0.256 & -0.860 & 0.00443 & 1.21 & -0.772 & -0.811 & -0.830 \\
Std. error kurtosis & 0.559 & 0.559 & 0.563 & 0.559 & 0.559 & 0.559 & 0.559 & 0.559 \\
Shapiro-Wilk p & 0.132 & 0.340 & 0.065 & 0.860 & 0.055 & 0.312 & 0.095 & 0.145 \\
\hline
\end{tabular}

Source: Authors' own calculations 
The final results have been extracted for three models of trade: Total trade, Exports and Imports. In all three models, we partially reject the null hypothesis that 'colonial links' have no impact on bilateral trade of India. It shows a positive and significant impact.

Results of Model-1 are given in Tables 2, 3 and 4. Table 4 shows three significant variables. GDP of trading partner and their geographical distance with India have significant impact on their bilateral trade with India. Findings show an inverse but significant relationship between geographical distance and bilateral trade, consistent with previous studies. Colonial link between trading partners is also found to have a significant and positive impact on bilateral trade.

Cultural distance has a negative though insignificant coefficient. There are different costs associated with different ways of serving a foreign market. There are broadly two ways to serve a foreign marketone is exporting and the other is to produce and sell locally (Caves 1996). Different authors have argued that larger cultural distance between countries leads to an increase in the cost of their bilateral trade. But, the cost is even higher in case of local production, which requires direct interaction with different stakeholders such as suppliers, employees, managers, government etc. who have different cultural backgrounds (Hennart 2000). The higher cost of producing in local market of culturally distant countries tends to make the other mode i.e. exporting an attractive one (Dunning, 1993).Our study however, finds that cultural distance between trading partners has no role in determining their bilateral trade.

Table 2: Model Fit Measures

\begin{tabular}{|c|c|c|c|c|c|c|c|c|c|}
\hline \multirow[b]{2}{*}{ Model } & \multirow[b]{2}{*}{$\mathrm{R}$} & \multirow[b]{2}{*}{$\mathrm{R}^{2}$} & \multirow[b]{2}{*}{ Adjusted $\mathrm{R}^{2}$} & \multirow[b]{2}{*}{$A I C$} & \multirow[b]{2}{*}{$B I C$} & \multicolumn{4}{|c|}{ Overall Model Test } \\
\hline & & & & & & $F$ & $d f 1$ & $d f 2$ & $p$ \\
\hline 1 & 0.782 & 0.611 & 0.575 & 95.3 & 113 & 16.8 & 6 & 64 & $<.001$ \\
\hline
\end{tabular}

Source: Authors' own calculations

Table 3: Collinearity Statistics

\begin{tabular}{ll}
\hline & VIF \\
\hline L_DIFF & 1.97 \\
L_TO & 1.50 \\
L_DIS & 1.37 \\
Cultural Distance & 1.52 \\
L_GDP & 1.45 \\
Col Link & 1.32 \\
\hline
\end{tabular}

Source: Authors' own calculations

Results of Model-2 are given in Tables 5, 6 and 7. Table 7 finding are similar to Model-1. GDP, geographical distance and colonial links have significant impact on India's export. Again, results show 
Impact of Cultural Determinants on Bilateral Trade of India

Table 4: Regression results for Trade and Cultural Distance

(Gravity Model 1)

\begin{tabular}{|c|c|c|c|c|}
\hline Predictor & Coefficient & Stderror & $t$ Value & PValue \\
\hline Intercept & -0.3646 & 1.3119 & -0.278 & 0.782 \\
\hline Log GDP & $0.8030^{*}$ & 0.0973 & 8.252 & $<.001$ \\
\hline Log Distance & $-0.5561^{*}$ & 0.2457 & -2.263 & 0.027 \\
\hline Colonial Link & $0.4033^{*}$ & 0.1330 & 3.033 & 0.003 \\
\hline Cultural Distance & -0.0216 & 0.0932 & -0.231 & 0.818 \\
\hline Log Per capita difference & -0.0941 & 0.1042 & -0.904 & 0.370 \\
\hline Log Trade Openness & 0.2923 & 0.2436 & 1.200 & 0.235 \\
\hline
\end{tabular}

Source: Authors' own calculations

Notes: *denote significance 5 percent.

that higher distance between trading partners leads to lower exports from India. Colonial links show a positive and significant impact on bilateral trade. The role of cultural distance on export is again found negative as found in previous studies but insignificant in our study. The other variables trade openness and per capita difference are also found insignificant.

Table 5: Model Fit Measures

\begin{tabular}{|c|c|c|c|c|c|c|c|c|c|}
\hline \multirow[b]{2}{*}{ Model } & \multirow[b]{2}{*}{$\mathrm{R}$} & \multirow[b]{2}{*}{$\mathrm{R}^{2}$} & \multirow[b]{2}{*}{ Adjusted $\mathrm{R}^{2}$} & \multirow[b]{2}{*}{$A I C$} & \multirow[b]{2}{*}{$B I C$} & \multicolumn{4}{|c|}{ Overall Model Test } \\
\hline & & & & & & $F$ & $d f 1$ & $d f 2$ & $p$ \\
\hline 2 & 0.795 & 0.631 & 0.597 & 82.1 & 100 & 18.3 & 6 & 64 & $<.001$ \\
\hline
\end{tabular}

Source: Authors' own calculations

Table 6: Collinearity Statistics

\begin{tabular}{ll}
\hline & VIF \\
\hline L_DIFF & 1.97 \\
L_TO & 1.50 \\
L_DIS & 1.37 \\
Cultural Distance & 1.52 \\
L_GDP & 1.45 \\
Col Link & 1.32 \\
\hline
\end{tabular}

Source: Authors' own calculations

Orissa Journal of Commerce, 42(3) (C) 2021 
Anurag Maurya and Shilpa Garg

Table 7: Regression Results for Exports and Cultural Distance (Gravity Model 2)

\begin{tabular}{|c|c|c|c|c|}
\hline Predictor & Coefficient & Stderror & t Value & PValue \\
\hline Intercept & 0.2393 & 1.1953 & 0.200 & 0.842 \\
\hline Log GDP & $0.7773^{*}$ & 0.0887 & 8.767 & $<.001$ \\
\hline Log Distance & $-0.6778^{*}$ & 0.2238 & -3.028 & 0.004 \\
\hline Colonial Link & $0.2634 *$ & 0.1212 & 2.174 & 0.033 \\
\hline Cultural Distance & -0.0222 & 0.0849 & -0.261 & 0.795 \\
\hline Log Per capita difference & -0.1487 & 0.0949 & -1.566 & 0.122 \\
\hline Log Trade Openness & 0.2566 & 0.2220 & 1.156 & 0.252 \\
\hline
\end{tabular}

Source: Authors' own calculations

Notes: *denote significance 5 percent.

Model-3 results are given in tables8, 9 and 10. The findings in table 10 show that only GDP of trading partner and their colonial link have a positive and significant impact on India's imports. All the other variables turned insignificant. The results indicate a negative relationship of imports with geographical distance and cultural differences as expected but the coefficients are insignificant.

Table 8: Model Fit Measures

\begin{tabular}{lrrrrrrrrrr}
\hline & & & & & \multicolumn{4}{c}{ Overall Model Test } \\
\cline { 6 - 11 } Model & $\mathrm{R}$ & $\mathrm{R}^{2}$ & Adjusted $\mathrm{R}^{2}$ & AIC & BIC & $F$ & $d f 1$ & $d f 2$ & $p$ \\
\hline 2 & 0.738 & 0.545 & 0.502 & 128 & 146 & 12.8 & 6 & 64 & $<.001$ \\
\hline
\end{tabular}

Source: Authors' own calculations

Table 9: Collinearity Statistics

\begin{tabular}{ll}
\hline & VIF \\
\hline L_DIFF & 1.97 \\
L_TO & 1.50 \\
L_DIS & 1.37 \\
Cultural Distance & 1.52 \\
L_GDP & 1.45 \\
Col Link & 1.32 \\
\hline
\end{tabular}

Source: Authors' own calculations

A comparison of Model-2 (exports) and Model-3 (imports) reveals that GDP is more significant for imports as compared to exports i.e. 0.89. Further, the larger geographical distances between trading 
Impact of Cultural Determinants on Bilateral Trade of India

Table 10: Regression Results for Imports and Cultural Distance (Gravity Model 3)

\begin{tabular}{lccrr}
\hline Predictor & Coefficient & Stderror & T Value & P Value \\
\hline Intercept & -3.5037 & 1.648 & -2.126 & 0.037 \\
Log GDP & $0.8914^{*}$ & 0.122 & 7.293 & $<.001$ \\
Log Distance & -0.0881 & 0.309 & -0.286 & 0.776 \\
Colonial Link & $0.6082^{*}$ & 0.167 & 3.642 & $<.001$ \\
Cultural Distance & -0.0317 & 0.117 & -0.270 & 0.788 \\
Log Per capita difference & -0.0670 & 0.131 & -0.512 & 0.610 \\
Log Trade Openness & 0.5761 & 0.306 & 1.883 & 0.064 \\
\hline
\end{tabular}

Source: Authors' own calculations

Notes: *denote significance 5 percent.

countries have a lesser impact on imports than exports. It also indicates that colonial link between India and its trading partner encourages their bilateral trade but it tends to import more from colonial linked countries as compared to exports to them. Cultural distance is found negative but insignificant for both exports and imports models.

\section{Conclusion}

The paper analyzes the role of cultural factors in determining India's bilateral trade with its 76 trading partner countries, using an extended gravity model of trade. While the existing literature has mostly focussed on few linguistic and religious aspects of culture, our study has used 'cultural distance' and 'colonial links' as cultural determinants, where 'cultural distance' between India and its trade partners is measured using the six dimensions of cultural framework i.e. power distance, uncertainty avoidance, masculinity vs. femineity, individualism vs. collectivism, long term vs. short term orientation and indulgence vs. restraints given by Hofstede et al. (2010).

The findings of the study revealed that there is a positive as well as significant effect of colonial links on bilateral trade of countries. The impact of colonial link is found significant for export as well as import between countries. The colonisation process leads to economic dominance and imposition of cultural, religious and administrative practices of coloniser on the other territories i.e. called as colonies. The colonial link between India and its trading partners shows that these colonies share similar economic and administrative policies with language, culture and religious practices. These similarities based on colonial link further facilitates bilateral trade between counties. Further, study examines the impact of cultural distance between countries on their trade relations. But results of the study show negative though insignificant effect of cultural distance on India's trading activities i.e. total trade, exports and imports. The extent of cultural distance is found irrelevant to facilitate trade between two countries. It is also found that GDP of the trading partner and geographical distance between India and its trading partners also play a major role in determining their bilateral trade. 
Anurag Maurya and Shilpa Garg

\section{References}

Barkema, H. G., \& Vermeulen, F. (1997). What differences in the cultural backgrounds of partners are detrimental for international joint ventures? Journal of International Business Studies, 28(4), 845-864.

Brouthers, K. D., \& Brouthers, L. E. (2001). Explaining the national cultural distance paradox. Journal of International Business Studies, 32(1), 177-189.

Caves, R.E. (1996). Multinational Enterprise and Economic Analysis, Cambridge, New York: Cambridge University Press.

Cyrus, T. L. (2012). Cultural distance and bilateral trade. Global Economy Journal, 12(4), 1850275.

De Groot, H. L., Linders, G. J., Rietveld, P., \& Subramanian, U. (2004). The institutional determinants of bilateral trade patterns. Kyklos, 57(1), 103-123.

Dunning, J.H. (1993). Multinational Enterprises and the Global Economy, Wokingham, UK: Addison-Westley Publishing Company.

Elsass, P.M. \& Veiga, J. F. (1994). Acculturation in Acquired Organizations: a force-field.

Felbermayr, G. J., \& Toubal, F. (2010). Cultural proximity and trade. European Economic Review, 54(2), 279-293.

Garg, S. (2019). Evolution of institutional environment in India: Formal and informal institutions. PRAGATI: Journal of Indian Economy,6(2), 61-81.

Gokmen, G. (2017). Clash of civilizations and the impact of cultural differences on trade. Journal of Development Economics, 127, 449-458.

Guo, R. (2004). How culture influences foreign trade: Evidence from the US and China. The Journal of SocioEconomics, 33(6), 785-812.

Hennart, J.F. (2000). Transaction Costs Theory and the Multinational Enterprise, in: C. Pitelis and R. Sugden (eds.), The Nature of the Transnational Firm, London: Routledge.

Hofstede, G. (1980). Culture and organizations. International Studies of Management \& Organization, 10(4), 15-41.

Hofstede, G. (1980). Motivation, leadership, and organization: Do American theories apply abroad?. Organizational dynamics, 9(1), 42-63.

Hofstede, G., Hofstede, G. J., \& Minkov, M. (2010). Cultures and organizations: Software of the mind (Vol. 3). New York: Mcgraw-hill.

Hofstede, G. (2013). National Culture. Retrieved from: http://geert-hofstede.com/national-culture.html

Kogut, B., \& Singh, H. (1988). The effect of national culture on the choice of entry mode. Journal of International Business Studies, 19(3), 411-432.

Linders, G. J., HL Slangen, A., De Groot, H. L., \& Beugelsdijk, S. (2005). Cultural and institutional determinants of bilateral trade flows. Retrieved from: https:// dx.doi.org/10.2139/ssrn. 775504 .

Park, S. H., \& Ungson, G. R. (1997).The effect of national culture, organizational complementarity, and economic motivation on joint venture dissolution. Academy of Management Journal, 40(2), 279-307.

Parkhe, A. (1991). Interfirm Diversity, Organizational Learning, and Longevity in GlobalPerspective. Human Relations, 47, 431-453.

Pöyhönen, P. (1963). A tentative model for the volume of trade between countries. Weltwirtschaftliches Archiv, 93100.

Shapiro, S. S. \& Wilk, M. B. (1965). An analysis of variance test for normality (complete samples). Biometrika. 52 (34), 591-611. 
Impact of Cultural Determinants on Bilateral Trade of India

Srivastava, R.K. \& Green, R.T. (1986).Determinants of Bilateral Trade Flows. Journal of Business, 59(4), 623-640. Tadesse, B., \& White, R. (2010). Does cultural distance hinder trade in goods? A comparative study of nine OECD member nations. Open Economies Review, 21(2), 237-261.

Tinbergen, J. J. (1962). Shaping the world economy; suggestions for an international economic policy. https://distancecalculator.globefeed.com/Distance_Between_Countries.asp https://www.britannica.com/topic/Western-colonialism https://www.sciencedirect.com/topics/social-sciences/colonialism https://www.nationalgeographic.com/culture/article/colonialism https://www.hofstede-insights.com/ 